\title{
POLITICAL DISCOURSE IN A TRANSITIONAL SOCIETY: BETWEEN THE SCYLLA OF ANARCHY AND THE CHARYBDIS OF TYRANNY
}

\author{
Yakovlev D. V., Yeremenko O. M.
}

Politicians in our times feed their clichés to television, where even those who wish to disagree repeat them... Everything happens fast, but nothing actually happens. Each story on televised news is "breaking" until it is displaced by the next one.

So we are hit by wave upon wave but never see the ocean

Timothy Snyder "On Tyranny: Twenty Lessons from the Twentieth Century"

\section{INTRODUCTION}

The role of discourse grows during major political changes. It is becoming one of the most important political resources used in the struggle for power in a transitional society. Discourse is at the same time an effective tool for protecting interests (whatever or whomever they may be) and the ground of the collision of information messages of different genres and orientation in the process of competition for domination in the public opinion.

Discourse presents current political and social practices (Fairclough, N. $(2000)^{1}$, Wodak, R., \& Meyer, M. $\left.(2001)^{2}\right)$, expresses social identities, political ideology, and culture. Even the very definition of the political culture in the modern world contains an inclusion in the discourse: “... we can define political culture as the aggregate of political ideas, knowledge, traditions and values ... which defines the political process and which is expressed through political discourse" (Ordukhanyan E. (2019)) .

Discourse is an important element in the analysis and construction of the relations of power: "Discourse forms and represents public opinion, mass representations, stereotypes, beliefs and prejudices. The anthropological

${ }^{1}$ Fairclough, N. (2000). Discourse, social theory, and social research: The discourse of welfare reform. Journal of Sociolinguistics, 4, pp.163-195. Doi: 10.1111 / 1467-9481.00110

${ }^{2}$ Wodak, R., \& Meyer, M. (2001). Critical discourse analysis: History, agenda, theory and methodology, In R. Wodak \& M. Meyer (Eds.), CDA Methods). London: Sage. pp. 2-21.

${ }^{3}$ Ordukhanyan, E. (2019). A comparative analysis of theoretical and methodological foundations of political culture. Wisdom, (1 (12)), 38-48. 
dimension of politics allows us to imagine the space of power struggles as a network of different discourses, visions of the past, present and future of man, power and society. After all, discourse always places particular importance on those political practices that take place at the level of an individual politician or social group. The discourse reflects and at the same time limits the social, epistemological and rhetorical practices of the group" (Eremenko A., Yakovlev D. (2019) $)^{4}$.

Discourse means that “... social properties or relations of, e.g, class, gender or ethnicity, are thus systematically associated with the structural units, levels, or strategies of talk and text embedded in their social, political and cultural contexts. The same is true of relations between social organizations, institutions, groups, roles, situations, power, or political decision making, on the one hand, and discourse structures, on the other hand ... In relationships of dominance, such ideological discourse may thus Serving to sustain or challenge social positions" (Van Dijk, T.A. (2006) $)^{5}$.

The latter is a crucial feature of the political discourse of a transitional society. The use of Critical Discourse Analysis allows revealing “... authentic everyday communication in institutional, media, political or other locations rather than sample sentences or sample texts constructed in linguists' minds" (it is noteworthy that it concerns the minds of political scientists and sociologists - D.Y., O.Y.) (Wodak, R., \& De Cillia, (2009)) ${ }^{6}$.

Researching the political discourse as a form of social practice allows noticing "...a dialectical relationship between particular discursive acts and the situations, institutions and social structures in which they are embedded: the situational, institutional and social contexts shape and affect discourse, and, in turn, discourses influence social and political reality. In other words, discourse constitutes social practice and is at the same time constituted by it. Through discourses, social actors constitute objects of knowledge, situations and social roles as well as identities and interpersonal relations between different social groups and those who interact with them. Furthermore, discursive acts are socially constitutive in a variety of ways. Firstly, they are largely responsible for the genesis, production and construction of particular social conditions.

${ }^{4}$ Eremenko A., Yakovlev D. (2019). "My dialektiku uchili ne po Gegelyu". Filosofiya v zerkale politicheskoy propagandy: popytka antropologicheskogo podkhoda ["We studied dialectics not according to Hegel". The philosophy in the mirror of political propaganda: an attempt to the anthropological approach] Current problems of philosophy and sociology, no. 24, pp. 10-23. https://doi.org/10.32837/apfs.v0i24.885

${ }^{5}$ Van Dijk, T.A. (2006). Ideological discourse analysis. Journal of Political Ideologies, 11(2), pp.115-140. DOI: 10.1080/13569310600687908

${ }^{6}$ Wodak, R., De Cillia, R., Reisigl, M., Liebhart, K., Hirsch, A., Mitten, R., \& Unger, J. (2009). The Discursive Construction of National Identity (2nd ed.). Edinburgh: Edinburgh University, $288 \mathrm{p}$. 
Secondly, they can contribute to the restoration, legitimation or relativisation of a social status quo (ante). Thirdly, discursive acts are employed to maintain and reproduce the status quo. Fourthly, the discursive practice may be effective in transforming, dismantling or even destroying the status quo (Wodak, R., \& De Cillia, (2009)) $)^{7}$.

The political discourse of a transitional society includes the use of the language of another one (in this case, the discourse of democratic countries) to describe and analyse its reality. The political discourse of a transitional society is often unable to "see" its own political reality without borrowing names, cliches, symbolic markers from other discourses. Because of this, it accepts the challenges of 1) anarchy and 2) returning to authoritarianism. In addition, the political discourse of the transitional society, most importantly for us, becomes the source of information about the desired social order. It becomes the practice of constructing the future.

This article offers an understanding of the political discourse in a transitional society. In Ukraine, the political discourse is being constructed as a clash of different "pictures of the world", remnants of Soviet clichés, linguistic and rhetorical borrowings from the discourse of democratic and capitalist countries. The political discourse is said to be uncivil. It is dominated by the influence of oligarchic groups that own media in Ukraine. Instead, civil society discourse is poorly represented. For a successful transition from authoritarianism to democracy and overcoming the challenges of anarchy in a "divided" Ukrainian society, it is necessary to demonstrate deep interaction between civil society discourse and political discourse, and to limit the influence of propaganda discourse.

\section{Uncivil Discourse in Ukraine. Limited Influence of Civil Society on Political Discourse}

In the age of transformations, discourse is a practical construction of visions of proper social order and political order that have yet to be built. The dialectical connection between discourse as a means of reflecting political and economic practices (Soviet, post-Soviet, etc.) and discourse as a reflection of the proper (in a sense true and desirable) is most clearly manifested in transitional societies. This is the essence of political transition. Discourse is not only a tool with the help of which they fight for the "right" picture of the world, the domination of public opinion by creating an attractive image of the future. It is the subject of political struggle, manipulation, and illusion in the era of "post-truth".

${ }^{7}$ Wodak, R., De Cillia, R., Reisigl, M., Liebhart, K., Hirsch, A., Mitten, R., \& Unger, J. (2009). The Discursive Construction of National Identity (2nd ed.). Edinburgh: Edinburgh University, $288 \mathrm{p}$. 
Ukrainian society is constantly discussing examples of political and economic practices, law and social behaviour in democratic societies that are broadcast by media discourse. Discourse not only reflects existing political practices. In a transitional society, the need to choose the purpose of the country's development ("democracy", "rule of law", "capitalism", "liberalism", "e-democracy", "resilience", "sustainability" etc.) is publicly declared and substantiated. Discourse becomes a "field of battle" of ideologies that are not represented in political activity. It promotes their legitimation, recognition by public opinion. This applies not only to ex-communist countries but also to EU countries that accept the challenges of integration and disintegration... study focuses on how European integration is debated in mass media, and how this affects democratic inclusiveness. Advancing integration implies a shift in power between governments, parliaments, and civil society. Behind debates over Europe's 'democratic deficit' is a deeper concern: whether democratic politics can perform effectively under conditions of Europeanization and globalization. It is... study on the Europeanization of media discourse and political contention to date, and a must-read for anyone interested in how European integration changes democratic politics and why European integration has become increasingly contested" (Koopmans, R., \& Statham, P. (2010)) ${ }^{8}$.

For over thirty years, transitional societies in Eastern Europe have been moving from Soviet socialism and authoritarian politics to capitalism and consolidated democracy. At the same time, they are included in global transformations related to the information society.

To a full extent, this applies to Ukraine, which, having fixed the regime of electoral democracy, occasionally experiences authoritarian spasms and overcomes them in the wake of the revolutionary waves of 2004 and 2013 2014. During the revolutions, the "eternal" question of political science "Who governs?" (Dahl, R. A. $(2005)^{9}$, Holland, H. M. (1963) $)^{10}$, and the winner of the presidential elections is trying to restore the authoritarian regime, even if it is called competitive authoritarianism (Way L. A. (2004)) ${ }^{11}$.

${ }^{8}$ Koopmans, R., \& Statham, P. (Eds.) (2010). The Making of a European Public Sphere. Media Discourse and Political Contention. Communication, Society and Politics. Cambridge: Cambridge University Press, 335 p. doi:10.1017/CBO9780511761010

${ }^{9}$ Dahl, R. A. (2005). Who Governs? Democracy and Power in an American City (2nd ed.). New Haven and London: Yale University Press, 355 p.

${ }^{10}$ Holland, H. M. (1963) Who governs? democracy and power in an american city By Robert A. Dahl 355 pp. New Haven and London: Yale University Press, 1961. Social Forces, vol. 41, pp. 322-323. Retrieved from: https://doi.org/10.2307/2573188

${ }_{11}$ Way, L. A. (2004). The Sources and Dynamics of Competitive Authoritarianism in Ukraine. Journal of Communist Studies and Transition Politics, 20:1, pp. 143-161. DOI:10.1080/ 13523270410001687145 
One of the major problems associated with researching the political discourse of a transitional society is determining the nature of transition, its ultimate purpose and intermediate stages. The situation is complicated by the presence of many competing visions of transition, from both internal and external players (actors). Even civil society, which is one of the main agents of transition, does not have a unified vision. "When civil society makes a 'transition' its label, it cannot be assumed that different civil society actors share compatible varieties of localist or radical transformationists discourses" (Feola, G., Jaworska, S. (2019)) $)^{12}$. The political discourse of a transitional society "... also contribute to shaping social imagination, motivations, and the debate around development, sustainability and society's future..." (Feola, G., Jaworska, S. (2019)) $)^{13}$.

In a transitional society, in the process of a struggle for power, organizational and institutional entities use a wide variety of resources. There are no restrictions here in the form of the institutions of consolidated democracy and the rule of law. In the political discourse of a transitional society, "archaic" meanings and symbols, myths of traditional societies, modern political ideologies, media technologies and postmodern practices intersect. This applies not only to discursive practices. The use of violence and economic pressure are becoming strategies of power. The political discourse is widely used to manipulate culture and religion, language and history. At the same time, one cannot underestimate the role of rationality in the construction of political discourse. Rationality in decision making and public policy, which peaked in the age of modernization, is a powerful accelerator of democratic transition. Even in ancient polises, the benefits of smart policy were realised, "Pericles of Athens was called not only "the first citizen", but also "a rational person" (Yakovlev, D.V. (2012)) $)^{14}$, "rationality is one of the fundamental foundations of the Modern Era, a democratic political institution. Without rationalization, it is impossible to imagine the processes of secularization (according to M. Weber "dissipation" of the political field), liberalization of economic, political, media spaces, pluralization, formation and development of the rule of law and civil

${ }^{12}$ Feola, G., Jaworska, S. (2019) One transition, many transitions? A corpus-based study of societal sustainability transition discourses in four civil society's proposals. Sustainability Science, 14, pp. 1643-1656. DOI https://doi.org/10.1007/s11625-018-0631-9

${ }^{13}$ Feola, G., Jaworska, S. (2019) One transition, many transitions? A corpus-based study of societal sustainability transition discourses in four civil society's proposals. Sustainability Science, 14, pp. 1643-1656. DOI https://doi.org/10.1007/s11625-018-0631-9

${ }^{14}$ Yakovlev, D.V. (2012) Mystectvo polityky z tochky zoru teoriji racionaljnogho vyboru [Art of politics in terms of the theory of rational choice] Proceedings of the Legal life of modern Ukraine: Mater., International Scientific Conf. Prof. Off-staff (Ukraine, Odesa, April 20-21, 2012) (ed. V.M. Dremin), Odessa: Phoenix, Vol. 1, pp. 211-213. 
society, professional management (bureaucracy), public policy, science and education, technological progress" (Yakovlev, D.V. (2014)) ${ }^{15}$.

The political discourse in a transitional society plays a very important role: "discourse is not just a referential tool that describes the social world; it is a symbolic means that constructs social realities through processes of naming, describing, informing, in short, through giving meaning to objects, situations and people. Language is the building block of discourse and the choice of language acts as a lens through which people, objects and situations are constructed. This lens will foreground certain features while marginalising others" (Feola, G., Jaworska, S. (2019)) ${ }^{16}$.

It must be free, rational and open to ensure the success of the transition. In order to build democracy in society, firstly, it must be constructed in the discourse. Does the political discourse in Ukraine meet these criteria? Obviously, it is more manipulative, reflecting the conflict of the owners of the media, oligarchs and bureaucracy (nomenclature) rather than the interests of large social groups. The former ones have a monopoly on the right to vote, forming the discourse by following selfish and narrow-minded interests. Oligarchic groups use symbolic capital to control the construction of discourse for the sake of domination in economics and politics.

The period of transition has become so long that it is suggested to abandon the term "transition": "The post-Cold War world has been marked by the proliferation of hybrid political regimes. In different ways, and to varying degrees, polities across much of Africa (Ghana, Kenya, Mozambique, Zambia, Zimbabwe), postcommunist Eurasia (Albania, Croatia, Russia, Serbia, Ukraine), Asia (Malaysia, Taiwan), and Latin America (Haiti, Mexico, Paraguay, Peru) combined democratic rules with authoritarian governance during the 1990s. Scholars often treated these regimes as incomplete or transitional forms of democracy. Yet in many cases these expectations (or hopes) proved overly optimistic. Particularly in Africa and the former Soviet Union, many regimes have either remained hybrid or moved in an authoritarian direction. It may therefore be time to stop thinking of these cases in terms of transitions to democracy and to begin thinking about the specific types of regimes they actually are" (Way, L. A. (2004)) ${ }^{17}$. Instead, "transition" remains a

15 Yakovlev, D.V. (2014) Pidkhid racionaljnogho vyboru v doslidzhenni mizhnarodnykh vidnosyn [Rational choice approach in the study of international relations].Scientific works. Politology, Vol 228, № 216. Retrieved from: http://politics.chdu.edu.ua/article/view/27684/24799

${ }^{16}$ Feola, G., Jaworska, S. (2019) One transition, many transitions? A corpus-based study of societal sustainability transition discourses in four civil society's proposals. Sustainability Science, 14, pp. 1643-1656. DOI https://doi.org/10.1007/s11625-018-0631-9

${ }^{17}$ Way, L. A. (2004). The Sources and Dynamics of Competitive Authoritarianism in Ukraine. Journal of Communist Studies and Transition Politics, 20:1, pp. 143-161. DOI:10.1080/13523270410001687145 
popular term in political, media, and scientific discourse. The idea of transition as a difficult and long-running process of achieving capitalism and consolidated democracy remains attractive to political elites and experts. The impact of civil society on transition will be limited as long as civil society is not actively involved in forming the political discourse. Nowadays, the political discourse in Ukraine can be called "oligarchic", because it is formed mainly by mass media belonging to oligarchic groups ${ }^{18}$. The political discourse is anti-civil (political discourse is actually uncivil), which means that it does not facilitate the transition from authoritarianism to democracy.

The country's political regime is facing difficult challenges, taking on the challenges of both anarchy and authoritarianism. These threats are easily identified in the conditions of occupation of Crimea, armed conflict and the presence of temporarily uncontrolled territories ${ }^{19}$.

The main danger of the political discourse of a transitional society is expressed in the title of this article. It lies in the squeeze of political discourse between two utopias. It is difficult to move to a real democracy from the utopias of anarchy and authoritarianism. The promise of rapid and understandable human happiness makes them utopias. In the case of authoritarianism, it is because of the dissolution of individuality in the group and the grandeur of the state, and in the case of anarchy, the rejection of any moral norms, social additions and collective interests. "Utopia and anarchy are not irreconcilable ideas, but are consistent only when "utopia points to an ideal life without becoming a plan, that is, a lifeless machine applied to living matter". As a nonplanned ideal, utopia "truly becomes the realisation of progress"... And the reason is that anarchists viewed 'the world of anarchy' as 'a spontaneous creation of the free, untrammelled spirit of the men ... not fettered to any previously formulated plans or dogmas'. A blueprint of anarchy, they continue, 'would be self-contradictory, internally inconsistent, and anathema to anarchists" (Kinna, R. (2005)) $)^{20}$.

In the political discourse of a transitional society, Stalinist totalitarianism and Brezhnev's authoritarianism are identified as starting points of transition. These are political regimes that have been abandoned and repelled in search of Brave New World (Huxley, A.(1969)) ${ }^{21}$. Instead, the purpose of transition has

${ }^{18}$ Komu nalezhatj najbiljshi ZMI v Ukrajini: opublikovano cikavu infoghrafiku [Who to find the most serious ZMI in Ukraine: a published infographi]. Apostrophe Retrieved from: https://apostrophe.ua/ua/news/society/2019-04-03/komu-prinadlejat-krupneyshie-smi-v-ukraineopublikovana-interesnaya-infografika/159113

19 Analytical report on the results of the research carried out among the population of temporarily uncontrolled territories. Ukrainian Institute of the Future. Retrieved from: https://www.uifuture.org/en/publications/reports/24339dumky/ta/nastroi/jyteliv/okupovanych/terytoriy

${ }^{20}$ Kinna, R. (2005). Anarchism: A Beginner's Guide, Oxford,180 p.

${ }^{21}$ Huxley, A.(1969). Brave New World. New York: Harper Brothers. 
become debatable. It is formulated as a choice between two utopias: authoritarian and anarchist. The role of political discourse is to justify the transit from the authoritarian system to the western forms of democratic governance, from Soviet socialism to capitalism. Discourse becomes one of the key elements in the transitional process, the construction of its purpose, stages, objects and subjects. The history of transition in Ukraine proves that discourse is initially formed, which, thanks to the borrowings from the discourse of Western democracies, substantiates the need for the introduction of certain institutions. In the process of implementation in the specific circumstances of post-Soviet society, these ideas are distorted and expressed in the creation of simulative, imperfect, but quite realistic bodies, structures and organizations. Their activities have little in common with the patterns of democratic discourse, but effectively protect the selfish interests of individual players (oligarchs and bureaucrats).

The changes in political practices affect institutional interaction and the combinations of elements of discourse in practices: "Social change in countries, organisations etc is often initiated with new discourses. This operates through a dissemination across structural and scalar boundaries which 'recontextualizes' new discourses. These may be enacted as new ways of (inter)acting including genres, inculcated as new ways of being including styles, as well as materialized in eg new ways of structuring space. Thus liberal and neoliberal discourses have been recontextualized in 'transitional' countries in CEE, and to varying degrees enacted in new ways of (inter)acting (eg in government, including government addressing and interacting with citizens as consumers), inculcated in new ways of being (eg people adopting the lifestyles and identities of consumers), and materialized in such new constructions of space as the "shopping mall" (Fairclough, N. (2005)) ${ }^{22}$.

Contemporary political discourse in Ukraine is being formed in the conditions of political mediatization. Under the influence of mediatization, political discourse is changing, and debate is turning into a television show. It is about the emergence of a new ruling class of media owners, editors, and authors -mediacracy: "The technological capabilities of the media and its outreach make it possible to speak of the emergence of a new actor in politics - a mediacracy that promotes the politicization of politics through the subordination of the political agenda to the criteria of format and rating of the media" (Yakovlev, D.V. (2014) ${ }^{23}$. And this, according to T. Snyder, is a threat

${ }^{22}$ Fairclough, N. (2005). Discourse in processes of social change: "Transition" in central and eastern Europe. British and American Studies, № 11, pp. 9-34.

${ }^{23}$ Yakovlev, D.V. (2014). Oponenty demokratiji: rolj "partiji vlady" ta mediakratiji u postradjansjkij polityci [Opponents of Democracy: The Role of the "Party of Power" and the Mediaocracy in Post-Soviet Politics]. Young scientist, vol. 9, pp. 198-201. Retrieved from: http://molodyvcheny.in.ua/files/journal/2014/9/49.pdf 
that promotes authoritarianism: "The effort to define the shape and significance of events requires words and concepts that elude us when we are entranced by visual stimuli. Watching televised news is sometimes little more than looking at someone who is also looking at a picture. We take this collective trance to be normal. We have slowly fallen into in" (Snyder T. (2017)) $)^{24}$. For transitional societies, the dynamic expansion of such a relatively new phenomenon as media policy poses particular threats. The Soviet "... individual who emerged from the vestige of "real communism" with censorship, an"iron veil", a black-and-white screen and the only candidate from the bloc of "communists and non-party" enters the dynamic global information world, where the biggest challenge for a choice is not the lack of information, but its redundancy. The role of the media, which, apart from the traditional functions, virtualize the political space, create "hyper-reality", and turn politics into a media process, is changing" (Yakovlev, D.V. (2014)) ${ }^{25}$.

An appropriate discourse order is created, which differs from both the Soviet and the democratic ones in styles and genres. It in characterized by new relationships between politics and the media, the creation of information networks, etc. However, it is not the voice of civil society. This is evident in the following.

Firstly, this is evident in the restoration of a particular type of political discourse in the post-Soviet countries - the discourse of propaganda in the media. It most clearly shows the trace of Soviet authoritarian discourse. In the mirror of political propaganda, the trend of the mediatization of politics is combined with manipulation, distortion of facts, outright lies. The discourse of propaganda may be rating, but it is uncivil. It spoils everything it touches: "In political discourse and especially in the discourse of propaganda the profanation of philosophical teachings is generally carried out, which inevitably leads to their distortion. In order to deconstruct this profanation, it is necessary to analyse the worldview bases of consciousness of the subjects of contemporary political and propaganda struggle (Eremenko A., Yakovlev D. (2019)) ${ }^{26}$.

${ }^{24}$ Snyder T. (2017). On Tyranny: Twenty Lessons from the Twentieth Century. New York: Tim Duggan Books, $126 \mathrm{p}$.

${ }^{25}$ Yakovlev, D.V. (2014). Oponenty demokratiji: rolj "partiji vlady" ta mediakratiji u postradjansjkij polityci [Opponents of Democracy: The Role of the "Party of Power" and the Mediaocracy in Post-Soviet Politics]. Young scientist, vol. 9, pp. 198-201. Retrieved from: http://molodyvcheny.in.ua/files/journal/2014/9/49.pdf

${ }^{26}$ Eremenko A., Yakovlev D. (2019). "My dialektiku uchili ne po Gegelyu". Filosofiya v zerkale politicheskoy propagandy: popytka antropologicheskogo podkhoda ["We studied dialectics not according to Hegel". The philosophy in the mirror of political propaganda: an attempt to the anthropological approach] Current problems of philosophy and sociology, no. 24, pp. 10-23. https://doi.org/10.32837/apfs.v0i24.885 
Secondly, political analytics is presented in the genre of an interview, complex economic and political ones are presented in a simplified way in order to promote content and increase the rating of programmes. Politicians and civil servants adopt the style of clothing and behaviour of show stars, actors and turn themselves into celebrities.

Thirdly, this is evident in the focus of political discourse on the process of transition (the imperfections of existing political institutions, the need to "improve", media scandals surrounding individual politicians) and the use of certain topics and cliches borrowed from the discourse of democratic countries for manipulation. The interaction of political discourse with other discourses, as well as with non-discursive aspects of the process of "transition", requires rethinking from the standpoint of the interdisciplinary approach of the phenomenon of "transition" and "a transitional society" to determine the specificity of Ukrainian transition, its perception of the community. Identifying the elements of discourse that represent the continuity of particular discursive practices or indicate that there are some political changes requires additional research.

In the contemporary agenda setting, a new research programme is being formed. It is aimed at exploring the discourse of transitional societies. Regardless of political discourse, the essence of transition cannot be covered. Political discourse shapes public opinion about the purpose of transition and its necessity. Furthermore, it offers alternatives to a political choice and creates new images, identities, and patterns of behaviour. The role of political discourse is extremely important not only in the post-communist context but also in the global one: "Discourse is central in generating new and alternative imaginaries of the future and in making previously unthinkable alternatives plausible and conceivable... A language of connection and regeneration has become prominent in a range of transition discourses that have emerged from the civil society worldwide... Discourses also matter in framing and identity making and have been shown to influence the level of engagement in collective mobilization for sustainability, household or individual proenvironmental action, as well as the establishment of coalitions for or against change. Along the same lines, Loorbach et al. (2016) highlight the importance of discursive framing as social construction of sustainability transitions in that it "can give rise to the potential for (seemingly) short-term pressures to become game changers", and for combinations of specific events to "help to orient, legitimize, guide, and accelerate deep changes in society" (Feola, G., Jaworska, S. (2019)) $)^{27}$.

${ }^{27}$ Feola, G., Jaworska, S. (2019) One transition, many transitions? A corpus-based study of societal sustainability transition discourses in four civil society's proposals. Sustainability Science, 14, pp. 1643-1656. DOI https://doi.org/10.1007/s11625-018-0631-9 


\section{Peculiarities of Ukrainian Transition in Mass Media Materials}

For Ukraine, which has been going through a stage of political transformation for over thirty years, the problem of determining the nature of transition and its peculiarities is of utmost importance. We are fully concerned with the question: "What is a transition?' This question is pertinent in understanding the motivation amongst scientists, policy makers, practitioners, business actors and community groups in transitioning society towards sustainability" (Silva, A., Stocker, L. (2018)) $)^{28}$.

After the collapse of the Soviet Union, the political discourse changed beyond recognition: the obsessions of Marxism-Leninism and the Soviet political "newspeak" disappeared almost entirely, and Gorbachev's "perestroika", "glasnost" and "new thinking" opened the floodgates (often uncritical and sometimes just meaningless) from Western discourse (Eremenko A., Yakovlev D. $(2019))^{29}$.

In the discourse of political science, modern Ukrainian society is called “divided" (Walker E. W. (2014) ${ }^{30}$; Riabchuk M. (2015) $)^{31}$ and the political regime is "hybrid" (Yakovlev D. (2015)) ${ }^{32}$.

The discourse of transition is presented in Ukraine in the mass media, scientific research, government documents, legal acts, speeches by politicians, political party programs, etc. In the Ukrainian media, considerable attention is paid to the nature of the political regime and the problem of transition. In the genres of analytical articles, commentaries, blogs and interviews, the issues of transition are regularly covered in the newspapers "Dzerkalo Tyzhna" (https://dt.ua/), and "Den" (https://day.kyiv.ua/en), the online edition of "Ukrainska Pravda" (https://www.pravda.com.ua/). Among the Englishlanguage sources, there is "KyivPost", the only English-language newspaper in

${ }^{28}$ Silva, A., Stocker, L. (2018). What is a transition? Exploring visual and textual definitions among sustainability transition networks. Global Environmental Change, vol. 50, pp. 60-74. Retrieved from: https://doi.org/10.1016/j.gloenvcha.2018.02.003

${ }^{29}$ Eremenko A., Yakovlev D. (2019). "My dialektiku uchili ne po Gegelyu". Filosofiya v zerkale politicheskoy propagandy: popytka antropologicheskogo podkhoda ["We studied dialectics not according to Hegel". The philosophy in the mirror of political propaganda: an attempt to the anthropological approach] Current problems of philosophy and sociology, no. 24, pp. 10-23. https://doi.org/10.32837/apfs.v0i24.885

${ }^{30}$ Walker, E. W. (2014). Ukraine: Divided Nation, Divided State. Eurasian Geopolitics. Retrieved from: http://eurasiangeopolitics.com/2014/03/14/ukraine-divided-nation-divided-state

31 Riabchuk M. (2015) "Two Ukraine's' Reconsidered" The End of Ukrainian Ambivalence? Studies in Ethnicity and Nationalism, vol. 15, no. 1, pp. 138-156.

${ }^{32}$ Yakovlev D. (2015) Political choice of Ukraine: alternatives to the Grand Duke and restriction of the last secretary general. Proceedings of the Social and political configurations of Modernity: Political Power in Ukraine and in the World: Materials of the 4th International Scientific and Practical Conference (Ukraine Kyiv, June 3-4, 2015) (eds G. Derlugyan, A.A. Melnichenko, P. V. Kutuev, A. A. Migalush), Kyiv: Talcom, pp. 39-41. 
Ukraine (https://www.kyivpost.com/), and reviews and analytics of the journal "Krytyka" (https://krytyka.com/en) where special attention is paid to understanding the essence of the post-Soviet transition, and all articles are offered on the website in both Ukrainian and English. This study will provide some examples and quotations that represent the distinctive themes and features of contemporary political discourse.

One of the main features of political discourse is its prevalence (it is most widely broadcast by the mass media) and the focus of information on the mass audience. In political discourse, there is a dialectical connection between the individual and the collective. Owing to the speed of information transmission, the mass character and the prevalence, individual opinions become collective ones and influence public opinions through thought leaders. Through the prism of the statements of individual politicians, journalists and experts, one can trace the general trends in the development of the political discourse of a transitional society. Such trends include overcoming the Soviet ambiguity of false bottom when one thing is publicly stated, and another is meant: "until recently ... the war is called "anti-terrorist operation", the political crisis is called "decentralization", and the capitulation is called "special status" (Pokaljchuk, O. (2015) $)^{33}$. The current political discourse in Ukraine O. Pokalchuk calls "authoritarian pluralism" in the article "Ynakodeistvye" (Pokaljchuk, O. (2015) $)^{34}$. This correlates with M. Minakov's definition of the state of Ukrainian transitional society as "competitive authoritarianism" (Minakov, M. (2016) $)^{35}$. In agreement with this, it should be noted that in the context of pluralism and the constant fierce struggle for limited resources in the transitional society, there is a growing risk of populism, from which there is one step both to authoritarianism and, taking into an account the division of the Ukrainian society, to anarchy. One of the leading Ukrainian intellectuals I. Dziuba sends an appeal which is aimed at the criticism of populist rhetoric, which simplifies all problems of a transitional society: “... a naive or even primitive view explains all troubles with incompetence (options - with unscrupulousness, irresponsibility and corruption) of ministers. Ministers are changing, however, troubles remain. The incompetent ones (corruptive ones, etc.) are replaced by those who reproached them for incompetence (corruption, etc.), and then the latter ones are accused of having a complete list of the same

${ }^{33}$ Pokaljchuk, O. (2015) Inakodija [Inakodiya]. Dzerkalo tyzhnja, № 43. Retrieved from: https://dt.ua/socium/inakodiya-_.html

${ }^{34}$ Pokaljchuk, O. (2015) Inakodija [Inakodiya]. Dzerkalo tyzhnja, № 43. Retrieved from: https://dt.ua/socium/inakodiya-_.html

${ }^{35}$ Minakov, M. (2016). A Decisive Turn? Risks for Ukrainian Democracy After the Euromaidan, In: Carnegie Regional Insight, Carnegie Endowment for International Peace, February 3. 
sins. And there is no end to this carousel" (Savenko, O. (2015)) $)^{36}$. Attention is repeatedly paid to overcoming manipulations and limiting the discourse of propaganda. To this end, the need to appeal to scientific knowledge, scientists, and intellectuals is reasonably stated. The role of science, scholars, and intellectuals are rarely mentioned in the discourse of a transitional society. Science is not identified as a source of knowledge and information to help find a way out of the crisis. This also applies to the materials of research, where the emphasis is placed on the need to restore authority to scholars and intellectuals. The following quotations are illustrating these principles:

1. Emphasis on the problem of a new social contract and the “... creation of an educational system for the discovery and development of human talents... the formation, support, propaganda and strengthening of the state ideology based on universal human values through the development of philosophy, culture, education and civil public media" (Stavnijchuk, M. $(2016))^{37}$;

2. "There are many intellectuals in Ukraine, but the national intellectual society has not been formed. Squabbling, politicking, narcissism, petty local selfishness and "it is neither my headache nor my piece of cake". The Internet crowd of the blogosphere has proven to be stronger and more influential than the most advanced and educated authority whether it is a scholar, a teacher, a doctor or a social activist." (Jermolajev A. (2017)) $)^{38}$;

3 . In the context of "hybrid war", it is very important to create "... a kind of "scientific hub", a certain point of application of efforts and knowledge to unite the efforts of scholars, representatives of state structures and bodies of the security and defence sector, civil society to provide the country's militarypolitical leaders with a strategic way out of the crisis" (Ghorbulin V. (2017)) ; $^{39}$;

4. The role of university historians as representatives of the class of "public intellectuals" in the transitional society is as follows: "As far as

${ }^{36}$ Savenko, O. (2015). Ivan Dzjuba: 'Mozhe, same teper formujetjsja politychna ukrajinsjka nacija, pro jaku vesj chas ghovorylosja': interv'ju [Ivan Dzuba: 'Maybe this is the moment the political Ukrainian nation is being formed, which has been talked about all the time': interview]. Dzerkalo tyzhnja. № 18. Retrieved from: https://dt.ua/personalities/ivan-dzyuba-mozhesame-teper-formuyetsya-politichnaukrayinska-naciya-pro-yaku-ves-chas-govorilosya-.html

${ }^{37}$ Stavnijchuk, M. (2016). Dvi Ukrajiny. Pole boju - Konstytucija [Two Ukraine. The battlefield is the Constitution]. Dzerkalo tyzhnja, № 23. Retrieved from: https:/dt.ua/article/ print/internal/dviukrayini-pole-boyu-konstituciya-ukrayini-sogodni-potribni-principovo-nova-

konstituciyanovi-gorizonti-suspilnogo-rozvitku-i-pravovih-oriyentiriv

${ }^{38}$ Jermolajev A. (2017). Majbutnje minlyve. Bo - zminjuvane [The future is changeable. Because it is changeable]. Dzerkalo tyzhnja, № 3. Retrieved from: https://dt.ua/article/print/ internal/maybutnye-minlive-bo-zminyuvane-_.htm

${ }^{39}$ Ghorbulin V. (2017). '2017-j: dali bude...'Je ['2017: will be ...'] Dzerkalo tyzhnja, № 24. Retrieved from: https://dt.ua/article/print/internal/2017-y-dali-bude-cinnisni-resursi-viyniimiru-ukrayinskiy-format-_.html 
academic historians are concerned, their role might be the following. Because many of the problems and challenges faced by societies have important historical and comparative dimensions, many of them unknown to politicians and ordinary citizens, historians might focus on demonstrating these broader contexts. From this perspective, the main task of historians is not to make correct predictions about future developments or to find ready-made solutions for current problems, but to formulate new, more appropriate questions that enable the public to expand their horizons and discover other, possibly more productive, ways of discussing problems" (Sklokin V. (2015)) ${ }^{40}$;

5. It is pointless to fight with a lie by using a "counter-lie" (an "alternative" lie). The only alternative to lying is reliable information. Unfortunately, we often neither see nor hear it ... And do we have an adequate idea of the social composition of the supporters of "separatism", their ideology and argumentation? There are not only bandits and alcoholics and the $\mathrm{H}$ do not use only Russian weapons. And the polemic with them should be conducted not only by weapons. You need to know them better and their motivation. Then it will be possible to respond to false propaganda with a word of truth. Up to now, we do not always succeed" (Savenko, O. (2015)) ${ }^{41}$.

Controversial topics for the political discourse of the transitional society have become the problem of changes to the Constitution ${ }^{42}$, language policy ${ }^{43}$, overcoming Corruption (Ordukhanyan, E. (2019)) $)^{44}$.

It should also be noted the process of "decommunization", which started with the adoption of the Law of Ukraine "On condemning the communist and national-socialist (Nazi) totalitarian regimes in Ukraine and prohibiting the propaganda of their symbolism" of April 9, 2015 ${ }^{45}$. The discussion on "decommunization" was started by the magazine "Krytyka" 46 .

${ }^{40}$ Sklokin V. (2015). Turning Public: Historians and Public Intellectual Activity in PostSoviet Ukraine, Krytyka. Retrieved from: https://krytyka.com/en/articles/turning-public-historiansand-public-intellectual-activity-post-soviet-ukraine?domain_switch=full

${ }^{41}$ Savenko, O. (2015). Ivan Dzjuba: 'Mozhe, same teper formujetjsja politychna ukrajinsjka nacija, pro jaku vesj chas ghovorylosja': interv'ju [Ivan Dzuba: 'Maybe this is the moment the political Ukrainian nation is being formed, which has been talked about all the time': interview]. Dzerkalo tyzhnja. № 18. Retrieved from: https://dt.ua/personalities/ivan-dzyuba-mozhesame-teper-formuyetsya-politichnaukrayinska-naciya-pro-yaku-ves-chas-govorilosya-.html

${ }^{42}$ Experts: Constitutional changes do not threaten national sovereignty). Retrieved from: https://www.kyivpost.com/article/content/ukraine-politics/experts-constitutional-changes-dontthreaten-national-sovereignty-397201.html, Published Sept. 4, 2015 at 5:35 pm)

43 Ukraine says new law does not restrict minority language rights By Veronika Melkozerova 29, 2017, Retrieved from: https://www.kyivpost.com/ukraine-politics/ukraineclarifies-new-education-bill-language-norm-enraged-hungary-romania-russia.html

${ }^{44}$ Ordukhanyan, E. (2019). A comparative analysis of theoretical and methodological foundations of political culture. Wisdom, (1 (12)), 38-48.

45 Pro zasudzhennja komunistychnogho ta nacional-socialistychnogho (nacystsjkogho) totalitarnykh rezhymiv $\mathrm{v}$ Ukrajini ta zaboronu propaghandy jikhnjoji symvoliky [On condemning 
A separate line of political discourse is devoted to the problem of occupation of Crimea, the armed conflict in Eastern Ukraine, its causes and consequences $^{47}$, conceptualization (Carroll J. (2015)) ${ }^{48}$, finding the ways out of the crisis ${ }^{49}$.

In the context of the problems of the transit society, political discourse emphasizes the interaction and correlation of democratization processes, ensuring the rule of law and fundamental freedoms of citizens and enhancing the country's defence capacity. To some extent, these tasks are contradictory to each other, but the rights and freedoms of citizens should be restricted, and the level of civil society's activity should not be reduced to increase its defence capacity. On the contrary, in an armed conflict, it is important to promote the voice of civil society in political discourse. The task of civil society in political discourse is to become the antithesis of propaganda.

\section{CONCLUSIONS}

This article has offered a comprehensive review of the examples of the contemporary political discourse of a transitional society. Two threats to a transitional society that relate to the status and the prospects of political discourse have been identified. The following challenges for the political discourse of a transitional society have been studied: 1) anarchy; 2) authoritarianism. They have been identified as the utopias that appeal to a mass consumer and hinder the formation of democratic political discourse, and therefore the transition to a consolidated democracy. The focus on the mass audience, manipulation by the oligarchic mass media, ambiguity are also the features of modern political discourse. The danger of ignoring scientific arguments and reducing attention to the views of scientists and intellectuals have been noted, the examples to illustrate this danger have been provided.

The main controversial topics of the current political discourse of the transitional society in Ukraine are 1) democratization; 2) armed conflict in

the communist and national-socialist (Nazi) totalitarian regimes in Ukraine and banning the propaganda of their symbolism] Law of Ukraine on April 9, 2015 № 317-VIII Retrieved from: https://zakon.rada.gov.ua/laws/show/317-19?lang=en

${ }^{46}$ Submit your opinion piece on 'decommunization' in Ukraine Krytyka, April, 2015. Retrieved from: https://krytyka.com/en/articles/submit-your-opinion-piece-decommunization-ukraine

${ }^{47}$ Geopolitics Against Democracy: Ukraine's Democratization and Russian Great Power Aspirations. Krytyka, June, 2018. Retrieved from: https://krytyka.com/en/ukraine-and-donbas-canwe-be-together-again/articles/geopolitics-against-democracy-ukraines

${ }^{48}$ Carroll J. (2015). Conceptualizing the War in Donbas Krytyka, October, 2015 Retrieved from: https://krytyka.com/en/community/blogs/conceptualizing-war-donbas

${ }^{49}$ Why the Fight for the Hearts and Minds of People in Donbas Remains Urgent Today. Krytyka, November, 2019. Retrieved from: https://krytyka.com / en / ukraine-and-donbas-can-webe-together-again / articles / why-fight-hearts-and-minds-people-donbas 
Eastern Ukraine and occupation of Crimea; 3) constitutional process; 4) language policy; 5) counteracting political corruption; 6) decommunization.

The emphasis has been placed on the uncivil status of contemporary political discourse. This means that it is formed by the influence of the oligarchic masses of the media. The voice of civil society is not heard. The threat of mediatization of politics and the effective counteraction to it (rationalization of political argumentation) have been described. The main point is that the lack of activity of civil society leads to the manipulation and the distortion of political discourse by the oligarchic mass media. As a result, the discourse of propaganda is formed. It is aimed at dividing society, creating the "image of an enemy", hate speech instead of political dialogue.

This is especially dangerous in the context of armed conflict, when the offensive on freedom of speech, the diminishing influence of civil society, in particular, in the formation of political discourse, explains the need to increase defence capabilities.

\section{SUMMARY}

The current political discourse in Ukraine is defined as "uncivil". It is determined that civil society does not sufficiently influence the formation of political discourse. Utopias are a major threat to the political discourse of a transitional society. They have a strong influence on public opinion and are therefore used to gain power. Utopias are expressed in the form of anarchy and authoritarianism. Utopias are exacerbated by political propaganda which is broadcast by the oligarchic mass media. The armed conflict in the East of Ukraine and the occupation of Crimea, constitutional process, language policy, counteraction to political corruption, etc. are among the main topics of political discourse that require the greater activity of civil society as an alternative to the "utopia" of the discourse of the oligarchic mass media.

\section{REFERENCES}

1. Analytical report on the results of the research carried out among the population of temporarily uncontrolled territories. Ukrainian Institute of the Future. Retrieved from: https://www.uifuture.org/en/publications/ reports/24339dumky/ta/nastroi/jyteliv/okupovanych/terytoriy (accessed 11 February 2020)

2. Carroll J. (2015) Conceptualizing the War in Donbas Krytyka, October, 2015 Retrieved from: https://krytyka.com/en/community/blogs/ conceptualizing-war-donbas (accessed 11 February 2020)

3. Dahl, R. A. (2005). Who Governs? Democracy and Power in an American City (2nd ed.). New Haven and London: Yale University Press, $355 \mathrm{p}$. 
4. Eremenko A., Yakovlev D. (2019). "My dialektiku uchili ne po Gegelyu". Filosofiya v zerkale politicheskoy propagandy: popytka antropologicheskogo podkhoda ["We studied dialectics not according to Hegel". The philosophy in the mirror of political propaganda: an attempt to the anthropological approach] Current problems of philosophy and sociology, no. 24, pp. 10-23. https://doi.org/10.32837/apfs.v0i24.885 (accessed 11 February 2020)

5. Experts: Constitutional changes do not threaten national sovereignty). Retrieved from: https://www.kyivpost.com/article/content/ ukraine-politics/experts-constitutional-changes-dont-threaten-nationalsovereignty-397201.html, Published Sept. 4, 2015 at 5:35 pm) (accessed 11 February 2020)

6. Fairclough, N. (2000). Discourse, social theory, and social research: The discourse of welfare reform. Journal of Sociolinguistics, 4, pp. 163-195. Doi: 10.1111/1467-9481.00110

7. Fairclough, N. (2005). Discourse in processes of social change: "Transition" in central and eastern Europe. British and American Studies, № 11, pp. 9-34.

8. Feola, G., Jaworska, S. (2019) One transition, many transitions? A corpus-based study of societal sustainability transition discourses in four civil society's proposals. Sustainability Science, 14, pp. 1643-1656. DOI https://doi.org/10.1007/s11625-018-0631-9

9. Geopolitics Against Democracy: Ukraine's Democratization and Russian Great Power Aspirations. Krytyka, June, 2018. Retrieved from: https://krytyka.com/en/ukraine-and-donbas-can-we-be-together-again/articles/ geopolitics-against-democracy-ukraines (accessed 11 February 2020)

10. Ghorbulin V. (2017). '2017-j: dali bude...'Je ['2017: will be ...'] Dzerkalo tyzhnja, № 24. Retrieved from: https://dt.ua/article/print/internal/ 2017-y-dali-bude-cinnisni-resursi-viyni-imiru-ukrayinskiy-format-_.html (accessed 11 February 2020)

11. Holland, H. M. (1963). Who governs? democracy and power in an american city By Robert A. Dahl 355 pp. New Haven and London: Yale University Press, 1961. Social Forces, vol. 41, pp. 322-323. Retrieved from: https://doi.org/10.2307/2573188 (accessed 11 February 2020)

12. Huxley, A. (1969). Brave New World. New York: Harper Brothers.

13. Jermolajev A. (2017) Majbutnje minlyve. Bo - zminjuvane [The future is changeable. Because it is changeable]. Dzerkalo tyzhnja, № 3. Retrieved from: https://dt.ua/article/print/internal/maybutnye-minlive-bozminyuvane-_.htm (accessed 11 February 2020) 
14. Kinna, R. (2009)Anarchism and the Politics of Utopia, In Davis, L., Kinna, R. Anarchism and Utopianism, Manchester: Manchester University Press, pp. 221-40.

15. Kinna, R. (2005). Anarchism: A Beginner's Guide, Oxford, 180 p.

16. Komu nalezhatj najbiljshi ZMI v Ukrajini: opublikovano cikavu infoghrafiku [Who to find the most serious ZMI in Ukraine: a published infographi]. Apostrophe Retrieved from: https://apostrophe.ua/ua/news/ society/2019-04-03/komu-prinadlejat-krupneyshie-smi-v-ukraineopublikovana-interesnaya-infografika/159113 (accessed 11 February 2020)

17. Koopmans, R., \& Statham, P. (Eds.) (2010). The Making of a European Public Sphere. Media Discourse and Political Contention. Communication, Society and Politics. Cambridge: Cambridge University Press, 335 p. doi:10.1017/CBO9780511761010 (accessed 11 February 2020)

18. Minakov, M. (2016). A Decisive Turn? Risks for Ukrainian Democracy After the Euromaidan, In: Carnegie Regional Insight, Carnegie Endowment for International Peace, February 3.

19. Oberkovych, S.( 2017) As 2017 wraps up, Ukraine remains a 'land of opportunity' By Brian Bonner. Retrieved from: https://www.kyivpost.com/ business/sergiy-oberkovych-2017-wraps-ukraine-remains-land-opportunities.htm (accessed 11 February 2020)

20. Ordukhanyan, E. (2019). A comparative analysis of theoretical and methodological foundations of political culture. Wisdom, (1 (12)), 38-48.

21. Pokaljchuk, O. (2015) Inakodija [Inakodiya]. Dzerkalo tyzhnja, № 43. Retrieved from: https://dt.ua/socium/inakodiya-_.html (accessed 11 February 2020)

22. Pro zasudzhennja komunistychnogho ta nacional-socialistychnogho (nacystsjkogho) totalitarnykh rezhymiv $\mathrm{v}$ Ukrajini ta zaboronu propaghandy jikhnjoji symvoliky [On condemning the communist and national-socialist (Nazi) totalitarian regimes in Ukraine and banning the propaganda of their symbolism] Law of Ukraine on April 9, 2015 № 317-VIII Retrieved from: https://zakon.rada.gov.ua/laws/show/317-19?lang=en (accessed 11 February 2020)

23. Riabchuk M. (2015) “Two Ukraine's' Reconsidered” The End of Ukrainian Ambivalence? Studies in Ethnicity and Nationalism, vol. 15, no. 1, pp. 138-156.

24. Savenko, O. (2015) Ivan Dzjuba: 'Mozhe, same teper formujetjsja politychna ukrajinsjka nacija, pro jaku vesj chas ghovorylosja': interv'ju [Ivan Dzuba: 'Maybe this is the moment the political Ukrainian nation is being formed, which has been talked about all the time': interview]. Dzerkalo tyzhnja. № 18. Retrieved from: https://dt.ua/personalities/ivan-dzyuba-mozhe-same- 
teper-formuyetsya-politichnaukrayinska-naciya-pro-yaku-ves-chas-govorilosya.html (accessed 11 February 2020)

25. Silva, A., Stocker, L. (2018). What is a transition? Exploring visual and textual definitions among sustainability transition networks. Global Environmental Change, vol. 50, pp. 60-74. Retrieved from: https://doi.org/ 10.1016/j.gloenvcha.2018.02.003(accessed 11 February 2020)

26. Sklokin V. (2015). Turning Public: Historians and Public Intellectual Activity in Post-Soviet Ukraine, Krytyka. Retrieved from: https://krytyka.com/ en/articles/turning-public-historians-and-public-intellectual-activity-post-sovietukraine?domain_switch=full (accessed 11 February 2020)

27. Snyder T. (2017) On Tyranny: Twenty Lessons from the Twentieth Century. New York: Tim Duggan Books, 126 p.

28. Stavnijchuk, M. (2016) Dvi Ukrajiny. Pole boju - Konstytucija [Two Ukraine. The battlefield is the Constitution]. Dzerkalo tyzhnja, № 23. Retrieved from: https://dt.ua/article/print/internal/dviukrayini-pole-boyu-konstituciyaukrayini-sogodni-potribni-principovo-nova-konstituciyanovi-gorizontisuspilnogo-rozvitku-i-pravovih-oriyentiriv (accessed 11 February 2020)

29. Submit your opinion piece on 'decommunization' in Ukraine Krytyka, April, 2015. Retrieved from: https://krytyka.com/en/articles/submityour-opinion-piece-decommunization-ukraine (accessed 11 February 2020)

30. Ukraine says new law does not restrict minority language rights By Veronika Melkozerova 29, 2017., Retrieved from: https://www.kyivpost.com/ ukraine-politics/ukraine-clarifies-new-education-bill-language-norm-enragedhungary-romania-russia.html (accessed 11 February 2020)

31. Van Dijk, T.A. (2006). Ideological discourse analysis. Journal of Political Ideologies, 11(2), pp.115-140. DOI: 10.1080/13569310600687908

32. Walker, E. W. (2014). Ukraine: Divided Nation, Divided State. Eurasian Geopolitics. Retrieved from: http://eurasiangeopolitics.com/2014/ 03/14/ukraine-divided-nation-divided-state (accessed 11 February 2020)

33. Way, L. A. (2004). The Sources and Dynamics of Competitive Authoritarianism in Ukraine. Journal of Communist Studies and Transition Politics, 20:1, pp.143-161. DOI:10.1080/13523270410001687145

34. Why the Fight for the Hearts and Minds of People in Donbas Remains Urgent Today. Krytyka, November, 2019. Retrieved from: https://krytyka.com/en/ukraine-and-donbas-can-we-be-together-again/articles/ why-fight-hearts-and-minds-people-donbas (accessed 11 February 2020)

35. Wodak, R., De Cillia, R., Reisigl, M., Liebhart, K., Hirsch, A., Mitten, R., \& Unger, J. (2009). The Discursive Construction of National Identity (2nd ed.). Edinburgh: Edinburgh University, 288 p. 
36. Wodak, R., \& Meyer, M. (2001). Critical discourse analysis: History, agenda, theory and methodology, In R. Wodak \& M. Meyer (Eds.), CDA Methods (pp. 2-21). London: Sage.

37. Yakovlev D. (2015) Political choice of Ukraine: alternatives to the Grand Duke and restriction of the last secretary general. Proceedings of the Social and political configurations of Modernity: Political Power in Ukraine and in the World: Materials of the 4th International Scientific and Practical Conference (Ukraine Kyiv, June 3-4, 2015) (eds G. Derlugyan, A.A. Melnichenko, P. V. Kutuev, A. A. Migalush), Kyiv: Talcom, pp. 39-41.

38. Yakovlev, D.V. (2012) Mystectvo polityky z tochky zoru teoriji racionaljnogho vyboru [Art of politics in terms of the theory of rational choice] Proceedings of the Legal life of modern Ukraine: Mater., International Scientific Conf. Prof. Off-staff (Ukraine, Odesa, April 20-21, 2012) (ed. V.M. Dremin), Odessa: Phoenix, Vol. 1, pp. 211-213.

39. Yakovlev, D.V. (2014) Oponenty demokratiji: rolj "partiji vlady" ta mediakratiji u postradjansjkij polityci [Opponents of Democracy: The Role of the "Party of Power" and the Mediaocracy in Post-Soviet Politics]. Young scientist, vol. 9, pp. 198-201. Retrieved from: http://molodyvcheny.in.ua/ files/journal/2014/9/49.pdf (accessed 11 February 2020)

40. Yakovlev, D.V. (2014) Pidkhid racionaljnogho vyboru v doslidzhenni mizhnarodnykh vidnosyn [Rational choice approach in the study of international relations]. Scientific works. Politology, Vol 228, № 216. Retrieved from: http://politics.chdu.edu.ua/article/view/27684/24799 (accessed 11 February 2020)

\section{Information about the authors:} Yakovlev D. V., Prof. dr hab.,

Dean of the Faculty of Psychology, Political Science and Sociology, National University Odessa Law Academy 23, Fontanska str., Odessa, 65009, Ukraine ORCID ID: orcid.org/0000-0003-2828-4669

Yeremenko O. M., Prof. dr hab., Head of the Department of Philosophy, National University Odessa Law Academy 23, Fontanska str., Odessa, 65009, Ukraine ORCID ID: orcid.org/0000-0002-2922-0643 